a welcome from the Commission, and has been followed by an enlargement of the personnel of that body. As is generally known, the effect of the Act is to throw upon the major local authorities, county and county borough councils, the duty of securing proper facilities for cancer treatment on behalf of people in their areas; this will of necessity call for close collaboration with members of the Radium Commission whose knowledge and experience of radiological methods as practised in all the important centres in the country should secure a high level of efficiency in treatment and economy in practical methods.

\section{Mortality in New York Hospitals}

DURING 1938, the mortality-rate in the New York City hospitals for contagious diseases fell to 1.8 per cent, the lowest to date. This figure compares favourably with a 4-6 per cent mortality in general hospitals. There were 2,109 cases of whooping-cough admitted to hospitals in 1938, or more than for any year in the last two decades. Of all the cases of diphtheria notified to the Health Department in $1938,43 \cdot 7$ per cent were admitted to hospital, while 31 per cent of the scarlet fever cases, 8 per cent of the measles cases and $16 \cdot 1$ per cent of the whoopingcough cases were sent to hospital.

\section{Antiquities from the Eumorfopoulos Collections}

ONE of the most interesting and important items in the sale of part of the Eumorfopoulos collections which took place at Messrs. Sotheby's rooms during May 28-31 was a third century B.c. toilet box. This was purchased by the National Arts Collection Fund for presentation to the British Museum (Bloomsbury). It is described as circular, with a diameter of $8 \frac{1}{4}$ inches and a height of $5 \frac{1}{2}$ inches. It is decorated in greenish-red lacquer on a thin layer of fabric. The straight sides and domed top are ornamented with scrolls, birds and stylized animals, while on the sides of the cover are represented a horseman, a tiger and. a charging bull on a chocolate brown ground enriched with silver inlay. With the box was a bronze mirror of the Warring States period (c. 481-221 B.c.) which had been found inside it. Among other antiquities of special interest was an example of the remarkable and rare bronze-covered wine vessels of the little-known Shang Dynasty (? 1766-? 1122 B.c.), this specimen having a silvery-green and red-brown patina, a Kmer female torso in grey limestone of the eleventh century of our era, a period of perhaps the greatest efflorescence of the Kmer art of southeastern Asia, and the magnificent gold furnishings of a fifteenth century Ming emperor's tomb.

\section{Recent Earthquakes}

During May 18-19, fifty people were killed and many injured at Mexicali near the border of the United States, where houses and Government buildings were damaged. Fifteen earthquakes were felt. In Africa strong shocks were felt on the night of May 19 on the Zululand coast, in Natal, in the
Transvaal and in the Limpopo area. The epicentre may have been off the Zululand coast. Local tremors were felt in the Rand. About 23.55 G.M.T. on May 18 local tremors were felt at Deganwy, North Wales, by Mr. Willoughby Gardner, who reported the matter to The Times. These may have been due to movement along the Conway fault system.

Over the same week-end strong shocks were recorded on Mr. J. J. Shaw's seismographs at West Bromwich, and Father Rowland states that the seismograph at Stonyhurst College Observatory recorded a strong shock lasting about three hours, commencing on May 19 about 4.40 G.M.T. At Kew the seismographs commenced recording on May 19 at $4 \mathrm{~h} .48 \mathrm{~m}$. 53s. G.M.T. and finished at 7h. $45 \mathrm{~m}$., with a maximum ground amplitude at Kew of $0.029 \mathrm{~mm}$. A second shock was registered at Kow at $15 \mathrm{~h} .29 \mathrm{~m}$. approximately on the same day, though this was only small.

\section{Announcements}

IT is announced that the British Association has reluctantly decided to cancel the Conference on Science in National and International Aspects which was to have been held at Reading during July 25-27.

Mr. T. L. Asquith, chemist, Royal Ordnance Factory, has been appointed an additional member of the Civil Division of the Order of the British Empire, for services in connexion with an explosion at the Royal Ordnance Factory on April 2.

THE following officers for 1940-41 of the Royal Aeronautical Society have recently been elected: President, Dr. A. H. R. Fedden; Vice-Presidents, Mr. Griffith Brewer and Air Vice-Marshal R. M. Hill; Honorary Treasurer, Major D. H. Kennedy ; Honorary Librarian, Mr. J. E. Hodgson ; Secretary and Editor, Captain J. Laurence Pritchard.

Mr. Donald C. Bradford has been appointed seismologist at the University of Pittsburgh. The seismological station is in the basement of the "Cathedral of Learning", a skyscraper close to the main traffic arteries of the city. It has been found that the two Wenner horizontal seismometers and the Benioff vertical seismograph function quite satisfactorily, contrary to expectations before 1931 when the site was tested and recording began.

ThE sixth University in the Argentine Republic has recently been founded at Mendoza.

More than 9,000 natives died from malaria in the Transvaal during the year ended March 31, 1939. According to the Department of Public Health the heavy rains at the end of 1938 and the beginning of 1939 made conditions favourable for malarial mosquitoes. The chief difference between this epidemic and that of 1937 was not one of severity but of extent, the 1939 epidemic reaching over a greater area and going so far south as Pretoria. 